\title{
Postpartum Anxiety Factors Involved Subjects Undergoing Cesarean Section as Analyzed by Zung Self Rating Anxiety Scale
}

\author{
Akbar Rahmat, ${ }^{1}$ Lucky Saputra, ${ }^{2}$ Akhmad Yogi Pramatirta, ${ }^{1}$ Udin Sabarudin, ${ }^{1}$ \\ Sofie Rifayani Krisnadi, ${ }^{1}$ Herman Susanto, ${ }^{1}$ Jusuf Sulaiman Effendi ${ }^{1}$ \\ ${ }^{1}$ Department of Obstetrics \& Gynecology, Faculty of Medicine Universitas Padjadjaran \\ Dr. Hasan Sadikin Hospital Bandung \\ ${ }^{2}$ Department of Psychiatry, Faculty of Medicine Universitas Padjadjaran \\ Dr. Hasan Sadikin Hospital Bandung \\ Korespondensi: Akbar Rahmat, Email: akbarrahmat123456@gmail.com
}

\begin{abstract}
Objective: postpartum mother who underwent cesarean section may experience anxiety. The risk factors associated with anxiety include age, education and income level, parity, social and cultural factors, delivery methods, as well as the history of pregnancy.

Methods: This study used analytic, cross-sectional method. Postpartum mother $(n=194)$ were recruited for this study. All participants consented to fill a questionnaire, to determine the subject's parameters and anxiety levels. Severity of postpartum anxiety was determined based on the Zung Self-rating Anxiety Scale (SAS).

Results: Postpartum anxiety (SAS $\geq 45$ ) were mostly found in the group experiencing emergency cesarean section $(71.13 \%)$ compared to the group with scheduled cesarean section $(32.1 \%)(\mathrm{p}<0.001)$. Forty-seven subjects $(82.5 \%)$ women aged $<20$ years old experienced postpartum anxiety, while $32.1 \%$ women aged $\geq 20$ years old were found to have similar condition $(\mathrm{p}<0.001)$. Subjects with lower education levels had a higher prevalence of postpartum anxiety than those with higher education levels $(73.4 \%$ vs $12.9 \%, p<0.001)$. Different income levels had $47.2 \%$ and $46.3 \%$ prevalence of postpartum anxiety respectively, but not statistically significant.

Conclusion: there was a correlation between anxiety score on women who experienced an emergency and scheduled cesarean section with age and education level.
\end{abstract}

Keywords: Cesarean section, age, education levels, income levels, parity, Zung Self-rating Anxiety Scale

\section{Beberapa Faktor yang Memengaruhi Kecemasan Pasien yang Menjalani Seksio Sesarea dengan Pemeriksaan Zung Self Rating Anxiety Scale}

\begin{abstract}
Abstrak
Tujuan: Kondisi pascaseksio sesarea dapat menimbulkan kecemasan ibu. Faktor yang dapat mempengaruhi timbulnya kecemasan antara lain usia, tingkat pendidikan, tingkat pendapatan, paritas, faktor sosial budaya, faktor jenis persalinan, dan riwayat persalinan yang lalu.

Metode: Penelitian ini menggunakan metode analitik cross-sectional. Wanita pasca seksio sesarea yang memenuhi kriteria penelitian $(n=194)$ dengan kuesioner. Tingkat kecemasan dinilai berdasarkan derajat Zung Self-rating Anxiety Scale (SAS).Penelitian dilakukan di RSUP Dr. Hasan Sadikin Bandung, RSUD Ujung Berung, RSKIA Kota Bandung, RSUD Soreang Kabupaten Bandung dari bulan Maret sampai dengan April 2017. Hasil: Penelitian ini menunjukan bahwa kecemasan postpartum ( $\mathrm{AS} \geq 45$ ) lebih banyak ditemukan pada pasien yang menjalani operasi sesar darurat (71,13\%) dibandingkan dengan pasien yang telah dijadwalkan terlebih dahulu $(32,1 \%)$ ( $p<0,001)$. Empat puluh tujuh pasien $(82,5 \%)$ wanita usia $<20$ tahun mengalami kecemasan pasca melahirkan, sementara $32,1 \%$ wanita berusia $\geq 20$ tahun ditemukan memiliki kondisi yang sama $(\mathrm{p}<0,001)$. Tingkat pendidikan $\leq$ SLTP memiliki prevalensi kecemasan lebih tinggi dibandingkan $>$ SLTA $(73,4 \%$ vs $12,9 \%, p<0,001)$. Tingkat pendapatan yang berbeda (lebih rendah dari UMR, sama atau lebih tinggi dari UMR) memiliki prevalensi pasca melahirkan sebesar 47,2\% dan 46,3\%, namun tidak signifikanberbeda secara statistik.
\end{abstract}

Kesimpulan: Terdapat perbedaan tingkat kecemasan pasca seksio sesarea pada kelompok seksio sesarea segera dibandingkan terencana dengan usia dan tingkat pendidikan.

Kata kunci: Seksio sesarea, usia, tingkat pendidikan, tingkat pendapatan, paritas, Zung Self-rating Anxiety Scale 


\section{Background}

Changes involved in becoming a mother is a complex psychological and developmental process, marked with several personal and familial adjustments that require adaptations. The birth of a baby could imply enormous changes in parents' lifestyles, sleeping patterns, sexual relationships, and social identity. ${ }^{1-3}$ Several studies have shown that during postpartum period, there are increased risks of anxiety, particularly for the mothers. ${ }^{3-6} \mathrm{Up}$ to $13 \%$ women experienced anxiety during pregnancy and/ or after delivery.

The prevalence of postpartum anxiety is increased in women around 20 years old, and pregnancy/delivery is potentially one of the crucial stressors. ${ }^{7-8}$ It is understandable that postpartum period is a critical time point and a predisposition for the occurrence of anxiety, in which women experienced role changes as a mother, with an increased burden and less sleeping time. ${ }^{3,4} \mathrm{~A}$ postpartum anxiety is commonly presented by depression feeling, excessive worries, insomnia, and changes in body weight. ${ }^{8}$ Hence, attention to postpartum anxiety phenomenon in mothers is urgently required because this condition may interrupt the roles of the new mothers, which in turn may cause significant distress and seriously interfere mother to baby interactions. This may lead to mothers' negligence, inhibited infant development, even infanticide..$^{6-8}$

History of psychiatric disorders, young age, primipara, history of obstetrics complications, low education and/or income levels, psychosocial factors, hormonal factors, and abdominal delivery have been reported as the risk factors that increase the prevalence of postpartum anxiety. ${ }^{6,7}$ The anxiety feeling is often related to fear of the delivery process, fear of mother or infant death, and fear of the healthcare worker. Subjects without history of psychiatric disorders have 2.5 times less risk of the incidence of postpartum anxiety compared to those with a history of psychiatric disorders. ${ }^{4,8}$ The cesarean section - especially emergency cesarean section - has the highest risk for postpartum anxiety compared to a planned cesarean section or a vaginal delivery., ${ }^{3-8}$

There are severalscales ormeasurements to assess anxiety levels, such as Zung Self Rating Anxiety Scale (SAS), Hamilton Rate Scale for Anxiety (HRS A), and Anxiety scale from the Institute for Personality and Ability Testing (IPAT), Taylor Manifestation of Anxiety Scale (T-MAS), and Test Anxiety Questionnaire. $^{5,6}$ Zung Self-rating Anxiety Scale (SAS) is a anxiety level rating for adult subjects using questionnaires based on the symptoms of anxiety disorders as described in the Diagnostic and Statistical Manual of Mental Disorders (DSM-II). It is commonly used in many previous studies because of its high validity and ease of use. Based on the answers to these questionnaires, anxiety levels are determined and classified as normal, mild-moderate, severe, or extreme. ${ }^{20}$

Understanding of risk factors for postpartum anxiety may give clinicians to screen for subjects with high risk and prescribe preventive measures readily and accordingly. This study was intended to analyze the difference of postpartum anxiety prevalence in subjects underwent both elective or emergency cesarean section, the role of age, parity, and socioeconomic factors using Zung Self-rating Anxiety Scale (SAS).

\section{Methods}

This was an analytical study with crosssectional approach. The study populations were women who underwent cesarean sections to deliver mature, live babies in Dr. Hasan Sadikin Central General Hospital Bandung and its satellite hospitals such as Hospital Astana Anyar, Hospital Kota 
Bandung, Hospital Ujung Berung, Hospital Soreang from 1 March 2017 until 31 April 2017. Participating subjects were ensured not to exhibit any underlying diseases or history of cesarean section and/or psychiatric disorders, and to have consented to participate in this study using individual signed informed consent. The study protocol had been reviewed and approved by the Dr. Hasan Sadikin Central General Hospital Research Ethics Committee Bandung (LB.04.01/A05/EC/243/VI/2016).

The characteristics of subjects: age $(<20$ years old or $\geq 20$ years old), education levels ( $\leq$ junior high or $>$ junior high), income levels $(<$ RMS or $\geq$ RMS; RMS $=$ Region Minimum Salary or Upah Minimum Regional), parity status (primipara or multipara), as well as anxiety levels as determined by Zung Selfrating Anxiety Scale (SAS) are the factors being analyzed in this study. The subjects were asked to answer SAS questionnaires during the third day postpartum.

Data were analyzed using IBM SPSS version 24.0 for Windows. Statistical analysis was performed to determine the normality of the data distribution using Shapiro Wilks method, followed by ChiSquare test to determine the significance of specific risk factor in its relation with the prevalence of subjects with high anxiety levels (SAS $\geq 45$ ).

\section{Results}

Total of 194 post-cesarean section subjects from five hospitals (RSUD Soreang, RSUD Ujung Berung, RSUD Kota Bandung, RSKIA Astana Anyar and RSUP Dr. Hasan Sadikin) during the period 1 March to 31 April 2017 participated in this study. No history of previous psychiatric disorders was diagnosed upon screening questionnaires.

Table 1. Characteristics of Study Subjects $(\mathrm{N}=194)$

\begin{tabular}{|c|c|c|c|c|c|c|c|}
\hline Characteristics & $\begin{array}{c}\text { Emergency } \\
\text { Cesarean } \\
\text { Section }\end{array}$ & $\%$ & $\begin{array}{l}\text { Planned } \\
\text { Caesarea } \\
\text { n Section }\end{array}$ & $\%$ & Total & $\%$ & p-value* \\
\hline Delivery method & 97 & 50 & 97 & 50 & 194 & 100 & \\
\hline Age $<20$ years old & 35 & 36.08 & 22 & 22.68 & 57 & 29.38 & 0.040 \\
\hline$\geq 20$ years old & 62 & 63.92 & 75 & 77.32 & 137 & 70.62 & \\
\hline Education levels & & & & & & & $<0.001$ \\
\hline$\leq$ Junior high & 67 & 69.07 & 42 & 43.30 & 109 & 56.19 & \\
\hline$>$ Junior high & 30 & 30.93 & 55 & 56.70 & 85 & 43.81 & \\
\hline Income levels & & & & & & & 0.651 \\
\hline Low $(<\mathrm{RMS})$ & 62 & 63.92 & 65 & 67.01 & 127 & 65.46 & \\
\hline $\operatorname{High}(\geq \mathrm{RMS})$ & 35 & 36.08 & 32 & 32.09 & 67 & 34.54 & \\
\hline Parity & & & & & & & 0.225 \\
\hline Primipara & 37 & 38.14 & 29 & 29.90 & 66 & 34.02 & \\
\hline Multipara & 60 & 61.86 & 68 & 70.10 & 128 & 65.98 & \\
\hline $\begin{array}{l}\text { SAS value } \\
<45\end{array}$ & 28 & 28.87 & 75 & 77.32 & 103 & 53.09 & $<0.001$ \\
\hline$\geq 45$ & 69 & 71.13 & 22 & 22.68 & 91 & 46.91 & \\
\hline
\end{tabular}

*Chi-square test

RMS $=$ Region Minimum Salary/Upah Minimal Regional (UMR) 
As shown in Table 1, from 194 study subjects, 97 subjects underwent emergency cesarean sections, and 97 subjects had planned cesarean sections. Fifty seven subjects $(29.38 \%)$ were aged $<20$ years old, while $137(70.62 \%)$ were $\geq 20$ years old. Low education levels ( $\leq$ junior high) were observed in 109 subjects $(56.19 \%)$, and the remaining 85 subjects (43.81\%) had education levels $>$ junior high. The low family income was found in $65.46 \%$ subjects, while higher income levels were found in $34.54 \%$ subjects. There are 66 subjects $(34.02 \%)$ were primipara, and 128 $(65.98 \%)$ were multipara. A total of 103 women $(53.09 \%)$ were classified as women with low anxiety levels (SAS <45), while the remaining 91 (46.91\%) had high anxiety levels ( $\mathrm{SAS} \geq 45$ ).

Statistically, there were significantly higher proportions of subjects with low education levels ( $\leq$ junior high) and also those with higher anxiety levels (SAS $\geq 45$ ) in the group with emergency cesarean section (Table 1).
In the $<20$ years old age group, it was observed that 47 subjects $(82.5 \%)$ had SAS $\geq 45$ compared to the 44 subjects $(32.1 \%)$ in those aged $\geq 20$ years old (Table 2 ). Eighty subjects $(73.4 \%)$ with education levels $\leq$ junior high experienced anxiety, while the incidence of postpartum anxiety in the group with education levels $>$ junior high was 11 subjects (12.9\%). The prevalence of postpartum anxiety subjects in the group with income levels <UMR was 60 subjects (47.2\%), and 31 subjects $(46.9 \%)$ for those with income levels $\geq U M R$. Postpartum anxiety incidence was found in 29 primipara subjects $(43.9 \%)$ and 62 multipara subjects $(48.4 \%)$.

Observations on the prevalence of subjects with lower anxiety levels (SAS $<45)$ compared to those with higher anxiety levels (SAS $\geq 45$ ) showed that statistically, the factors that influence anxiety incidence include methods of delivery, age, and education levels (Table 1 and Table 2). Prevalence of subjects with high anxiety levels was greater in the group

Table 2 Relations between Prevalenceof Subjects with Postpartum Anxiety and Subject Characteristics as Risk Factors

\begin{tabular}{|c|c|c|c|c|c|}
\hline \multirow[t]{2}{*}{ Characteristics } & \multicolumn{4}{|c|}{ Cesarean section } & \multirow[t]{2}{*}{ p-value* } \\
\hline & $\mathrm{SAS}<45$ & $\%$ & $\mathrm{SAS} \geq 45$ & $\%$ & \\
\hline Age & & & & & $<0.001$ \\
\hline$<20$ years old & 10 & 17.5 & 47 & 82.5 & \\
\hline$\geq 20$ years old & 93 & 67.9 & 44 & 32.1 & \\
\hline Education levels & & & & & $<0.001$ \\
\hline$\leq$ Junior high & 29 & 26.6 & 80 & 73.4 & \\
\hline$>$ Junior high & 74 & 87.1 & 11 & 12.9 & \\
\hline Income levels & & & & & 1.000 \\
\hline$<\mathrm{UMR}$ & 67 & 52.8 & 60 & 47.2 & \\
\hline$\geq \mathrm{UMR}$ & 36 & 53.7 & 31 & 46.3 & \\
\hline Parity & & & & & 0.649 \\
\hline Primipara & 37 & 56.1 & 29 & 43.9 & \\
\hline Multipara & 66 & 51.6 & 62 & 48.4 & \\
\hline
\end{tabular}

*Chi-square test 
experiencing emergency cesarean sections $(71.13 \%$ vs $22.68 \%, \mathrm{p}<0.001)$, aged $<20$ years old $(82.5 \%$ vs $32.1 \%, \mathrm{p}<0.001)$ and education levels $\leq$ junior high $(73.4 \%$ vs to $12.9 \%, \mathrm{p}<0.001)$. However, no significant difference was observed in the prevalence of postpartum anxiety subjects against income levels $(p=1.000)$ or parity $(p=0.649$, Table 2).

\section{Discussion}

This study was aimed to analyze the influence of several characteristics among women underwent different cesarean section methods (emergency or planned), such as age, education levels, income levels, and parity; in relation to the anxiety levels as determined by Zung Self-rating Anxiety Scale (SAS).

The postpartum anxiety incidence was higher in the emergency cesarean section group compared to planned cesarean section group, and was statistically significant.This finding was in agreement with the observation reported in one study, that cesarean section delivery method was one of the risk factors for the incidence of postpartum anxiety, especially within the five days postpartum. ${ }^{3}$

Anxiety in women with cesarean section could be caused by the imbalance between mothers' expectancy and the reality. Usually, women expected normal delivery, which when suddenly faced with the need to have an emergency cesarean section, might result in the emergence of negative feelings such as the feeling of failure, disappointment, or the loss of control. These conditions may trigger the incidence of postpartum anxiety.

In addition to the delivery method, many other factors have also been associated with postpartum anxiety, such as age, education levels, income levels, parity, environmental factors, sociocultural factors, unexpected pregnancy, and the mothers' mental preparedness in dealing with pregnancy, delivery, and the new baby. However, there also have been many discussions on which factors are the major stimuli. ${ }^{7}$

In addition to the delivery method, we also analyzed age, education and income levels, as well as parity factors. It was observed that young aged mothers $<20$ years old and those with lower education levels $\leq$ junior high had significantly increased prevalence of postpartum anxiety. The difference was not observed for the different income levels and primipara or multipara groups. Other studies also reported that women aged $<20$ years old tend to have less financial support, which might play as an added stressor in facing the change of having a newborn child, and could play as a trigger for postpartum anxiety $9-10,18,20$

This was a cross-sectional study, which only observed the mothers at one time point and could not describe the roles of previous pregnancy/delivery conditions, the use of social media, and the roles of health insurance or government financial aids that might be received by these mothers.

It is recommended to provide consultation and support forwomen at labor, especially those who underwent emergency cesarean section, at a young age, and/or have lower education levels. Early screening using SAS questionnaire could be the initial steps to detect risks as early as possible and prevent the incidence of postpartum anxiety. To confirm this observation, further studies using a different approach - such as a cohort study - with larger set of subjects is required. Preferably, future studies should take into account the difference between subjects that have insurance against those who do not have insurance and groups that are supported by governmental financial aid compared to those who do not receive such support. Differential analysis of these groups may give a more accurate data on the risk factors of postpartum anxiety and may be of benefits in clinical applications. 
In conclusion, it was observed that the prevalence of subjects with postpartum anxiety was higher in women post emergency cesarean section, aged $<20$ years old, and those with lower education levels $\leq$ junior high. The income levels and parity status factors were not indicated as risk factors for postpartum anxiety in this study.

\section{References}

1. Condon JT, Boyce P, Corkindale CJ. The First-Time Fathers Study: a prospective study of the mental health and wellbeing of men during the transition to parenthood. Aust NZJ Psychiatry. 2004;38(1-2):56-64.

2. Lowenstein L, Mustafa S, Burke Y. Pregnancy and normal sexual function. Are they compatible? J Sex Med. 2013;10(3):621-2.

3. CloutDandBrownR. Sociodemographic, pregnancy, obstetrics and postnatal predictors of postpartum stress, anxiety and in new mothers. J Affect Disord. 2015; 188:60-7.

4. Jackson LC, Robinson K. Prevalence of Wenzel A, Haugen EN, Prevalence of generalized anxiety at eight weeks postpartum. Arch Womens Ment Health. 2003;6(1):43.

5. Enatescu VR, Enatescu I, Craina M, Gluhovschi A, Papava I, Romosan $\mathrm{R}$, et al. State and trait anxiety as a psychopathological phenomenon correlated with postpartum in a Romanian sample: a pilot study. J Psychosom Obstet Gynaecol. 2014;35(2):55-61.

6. Martini J, Petzoldt J, Einsle F, BeesdoBaum K, Hofler M, Wittchen HU. Risk factors and course patterns of anxiety and depressive disorders during pregnancy and after delivery: a prospective-longitudinal study. J Affect Disord. 2015;175:385-95.
7. Bennett HA, Einarson A, Taddio A KG, Einarsson TR. Prevalence of anxiety during pregnancy: systematic review. Obstet Gynecol. 2004;103(4):698-709.

8. Rubertsson C, Hellstorm J, Cross M, Sydsjo G. Anxiety in early pregnancy: prevalence and contributing factors. Arch Womens Ment Health. 2014;17(3):221-8.

9. Arch JJ. Pregnancy-specific anxiety: which women are highest and what are the alcohol-related risks. Compr Psychiatry. 2013;54(3):217-28.

10. American Psychiatric Association. Diagnostic and Statistical Manual of Mental Disorders. $5^{\text {th }}$ ed. 2013; Arlington, VA: American Psychiatric Publishing.

11. Dennis CL, Coghlan M, Vigod S. Can we identify mothers at-risk for postpartum anxiety in the immediate postpartum period using the State-Trait Anxiety Inventory? J Affect Disord. 2013;150(3):1217-20.

12. Helle N, Barkman C, Ehrhardt S, von der Wense A, Nestoriuc Y, Bindt C. Postpartum anxiety and adjustment disorders in parents of infants with very low birth weight: Cross-sectional results from a controlled multicenter cohort study. J Affect Disord. 2016;194:12834.

13. Dubber S, Reck C, Muller M, Gawlik S. Postpartum bonding: the role of perinatal anxiety and maternal-fetal bonding during pregnancy. Arch Womens Ment Health. 2015;18(2):187-95.

14. Broekman BF, Chan YH, Chong YS, Kwek K, Cohen SS, Haley CL, et al. Gusto Research Group. The influence of anxiety and depressive symptoms during pregnancy on birth size. Paediatr Perinat Epidemiol. 2014;28(2):116-26.

15. Van den Heuvel MI, Johannes MA, Henrichs J, van den Bergh BR. Maternal mindfulness during pregnancy and 
infant socio-emotional development and temperament: the mediating role of maternal anxiety. Early Hum Dev. 2015;91(2):103-8.

16. Latendresse $\mathrm{G}$. The interaction between chronic stress and pregnancy: preterm birth from a biobehavioral perspective. Journal of Midwifery \& Women's Health. 2009;54(1):8-17.

17. Weisman $\mathrm{O}$, Granat A, GilboaSchechtman E, Singer M, Gordon I, Azulay H, et al. The experience of labor, maternal perception of the infant, and the mother's postpartum mood in a lowrisk community cohort. Arch Womens Ment Health. 2010;13(6):505-13.
18. Fatoye FO, Oladimeji BY, Adeyemi AB. Difficult delivery and some selected factors as predictors of early postpartum psychological symptoms among Nigerian women. J Psychosom Res. 2006;60(3):299-301.

19. Stjernholm YV, Petersson K, Eneroth E. Changed indications for cesarean sections. Acta Obstet Gynecol Scand. 2010;89(1):49-53.

20. Zung WWK. The measurement of affects: depression and anxiety. In Pichot P, Olivier-Martin R, eds. Psychological measurements in psychopharmacology. $1^{\text {st }}$ ed. Basel: Karger; 1974. pp.170-88. 